\title{
Comparison of two bone markers with growth evolution in 74 girls with central precocious puberty
}

\author{
Audrey Vincent ${ }^{1}$, Jean-Claude Souberbielle ${ }^{2}$ and Raja Brauner ${ }^{1 *}$
}

\begin{abstract}
Background: The bone markers bone alkaline phosphatase (BAP) and C-terminal telopeptide of type I collagen crosslinks (CTX) are correlated with growth rate during normal puberty. The objective of this study was to evaluate the relationship between the serum concentrations of BAP and CTX and growth evolution in girls with idiopathic central precocious puberty (CPP) to help predict adult height.

Methods: A retrospective single-center study was conducted in 74 girls with CPP for whom a serum sample at initial evaluation was available to retrospectively measure BAP and CTX concentrations; $66.2 \%$ of them were untreated.

Results: The serum BAP concentrations showed significant positive correlations with height in standard deviations (SDS) at the initial evaluation $(n=62 ; r=0.31 ; p=0.015)$ and with the difference between bone and chronological ages $(n=61 ; r=0.39 ; p=0.002)$. BAP was also positively correlated with adult height as measured in both $\mathrm{cm}$ and SDS in untreated patients $(n=19 ; r=0.58 ; p=0.009)$.

The serum CTX concentrations showed significant positive correlations with growth rate the year before the initial evaluation as measured in both $\mathrm{cm}$ and $\operatorname{SDS}(n=65 ; r=0.34 ; p=0.006)$.

Conclusions: This study revealed significant correlations of serum BAP and CTX concentrations with growth evolution in girls with CPP. The high positive correlation between serum BAP and adult height in untreated girls suggests that BAP can possibly be used to optimize models of adult height prediction in girls with CPP.
\end{abstract}

Keywords: Bone markers, Growth evolution, Central precocious puberty, Adult height, Bone alkaline phosphatase, CTX

\section{Background}

Biochemical markers of bone turnover are routinely used in clinical practice to monitor osteoporosis in post-menopausal women [1]. In addition, such markers are being documented and utilized in children more frequently than in the past. Among these biochemical markers, bone alkaline phosphatase (BAP) is a marker of bone formation present in the membrane of the osteoblasts and released into the circulation. BAP is a more sensitive diagnostic tool than total alkaline phosphatase activity [2]. In contrast, C-terminal telopeptide of type I collagen crosslinks (CTX) is a marker of bone resorption

\footnotetext{
*Correspondence: raja.brauner@wanadoo.fr

${ }^{1}$ Fondation Ophtalmologique Adolphe de Rothschild and Université Paris Descartes, 75940 Paris, France

Full list of author information is available at the end of the article
}

that is generated from translational modification of bone collagen and is released during matrix resorption [2].

Some previous studies have evaluated these markers in healthy girls during puberty [3-7]. For example, it was demonstrated that BAP and CTX concentrations vary with chronological age $[5,6]$ and pubertal Tanner stage [3-6], which has led to established reference values $[6,7]$. The peak levels of these bone markers occurred at Tanner breast stage 3 and decrease to adult concentrations at the end of puberty [3-6]. It has also been shown that BAP is positively correlated with growth rate $(\mathrm{cm} /$ year) during normal puberty [5].

Central precocious puberty (CPP) in girls is defined as the development of sexual characteristics before the age of 8 years due to premature activation of the hypothalamic-pituitary-ovarian axis [8]. In girls, CPP

(c) The Author(s). 2018 Open Access This article is distributed under the terms of the Creative Commons Attribution 4.0 International License (http://creativecommons.org/licenses/by/4.0/), which permits unrestricted use, distribution, and 
is idiopathic in the majority of cases [9]. Genetic [10, 11] and/or environmental factors, particularly obesity, contribute to early onset of puberty. An analysis of the presentation of 493 consecutive girls with CPP in a single-center study showed that obesity accelerates adrenarche but not maturation of the hypothalamic-pituitary-ovarian axis, which mainly depends on genetic factors [12].

Premature secretion of estradiol increases the growth rate and accelerates bone maturation, which can shorten the growing period, resulting in short adult height $(\mathrm{AH})$. Treatment with a gonadotropin-releasing hormone $(\mathrm{GnRH})$ analog blocks the pituitary-ovarian axis and thus estradiol secretion, thereby slowing bone age (BA) progression and preserving growth potential [13]. However, the effect of this treatment on $\mathrm{AH}$ varies, primarily because idiopathic $\mathrm{CPP}$ progression differs between unsustained forms, also called slowly progressing forms [14], and rapidly progressing forms [15].

Despite the breadth of reported data concerning $\mathrm{AH}$ in girls with idiopathic CPP, major questions remain about the indications for GnRH analog treatment [16]. As the reported height gain ( $\mathrm{AH}$-predicted $\mathrm{AH}$ at onset of treatment) varies from 0.3 [17] to $9.8 \mathrm{~cm}$ [18], it is difficult to determine whether to treat a given girl who has idiopathic CPP with GnRH analogs. Tools have been developed to predict AH in girls with CPP [19], but bone markers have not been used to date.

In this study, serum concentrations of BAP and CTX in girls with CPP were examined in relation to patient characteristics at initial evaluation, to growth rates at 6 months and 1 year after this evaluation, and to $\mathrm{AH}$ after spontaneous growth. The objective was to evaluate the relationship between serum concentrations of BAP and CTX and the growth evolution in girls with idiopathic CPP to help predict $\mathrm{AH}$.

\section{Methods}

\section{Study design}

We conducted a single-center study in girls who had been monitored for idiopathic CPP by a senior pediatric endocrinologist ( $R$. Brauner) in a university pediatric unit from June 1981 to July 2012 and for whom a serum sample at initial evaluation preserved at $-22{ }^{\circ} \mathrm{C}$ was still available to retrospectively measure serum BAP and CTX concentrations.

\section{Participants}

All clinical investigations were conducted according to the principles outlined in the Declaration of Helsinki. Written informed consent for the evaluation was obtained from the children's parents and included in their hospital medical record. With the exception of routine patient care, no other activities were performed for the study. The authors had no direct interaction with the patients enrolled in the study, except for their medical follow-up, which was performed by R. Brauner. Patients derived from a previous study [12] which was approved by the Ethical Review Committee (Comité de Protection des Personnes, Ile de France III) (Ref. CPP: AC 038), which states that "This study appears to be in accordance with scientific principles generally accepted and to ethical standards of research; this study was lead in the respect of the French law and regulation".

The primary outcome was to evaluate the relationship between serum concentrations of BAP and CTX and the growth evolution, mainly the $\mathrm{AH}$ after spontaneous evolution. The secondary outcome was to compare these concentrations to the patient characteristics at initial evaluation.

The 74 girls included were selected from 493 girls with CPP [12]. At the initial evaluation, the characteristics of the 74 girls included in the study were similar to those of the 419 girls without available samples, except for basal FSH concentration and peak, which were significantly lower in the included patients (Table 1).

In all patients, CPP was diagnosed based on the appearance of breast development before the age of 8 years, accompanied by the presence of pubic or axillary hair $(n=47 / 74 ; 63.5 \%)$, a growth rate greater than 2 standard deviations (SDS) the year before the initial evaluation $(n=32 / 70 ; 45.7 \%)$, and/or BA more than 2 years greater than their chronological age $(n=24 / 73$; $32.9 \%$ ). (Table 1). We also considered CPP, but not premature thelarche, for girls for whom breast development at initial evaluation was clinically isolated $(n=13 / 74 ; 17.6 \%)$ but associated with a uterus length greater than $35 \mathrm{~mm}$ on ultrasound ( $n=4 / 9$ evaluated), a luteinizing hormone (LH)/ follicle stimulating hormone (FSH) peak ratio greater than 0.66 by a $\mathrm{GnRH}$ test $(n=7 / 13)$, and/or a serum estradiol concentration greater than $15 \mathrm{pg} / \mathrm{mL}(n=6 / 13)$. According to these criteria, only 3 girls (4\%) had isolated breast development at initial evaluation, but their clinical picture became complete before 8 years of age, with ages at first menstruation of 10 and 11.5 years in the 2 patients for whom this information is available.

\section{Methods}

Organic intracranial lesions were excluded by neuroradiological evaluation except in 12 cases (16.2\%) with a familial history of early puberty, age greater than 6 years at onset of puberty, normal neurological evaluation, prepubertal serum estradiol concentrations and LH/FSH peak ratio $<0.66$.

The patients were assigned to one of two groups: treated patients $(n=25 / 74,33.8 \%)$ had been given a GnRH ana$\log$, whereas untreated patients $(n=49 / 74,66.2 \%)$ were followed without treatment. The criteria for treatment were a predicted $\mathrm{AH}<155 \mathrm{~cm}$ at initial evaluation $(n=4)$, 
Table 1 Patients characteristics

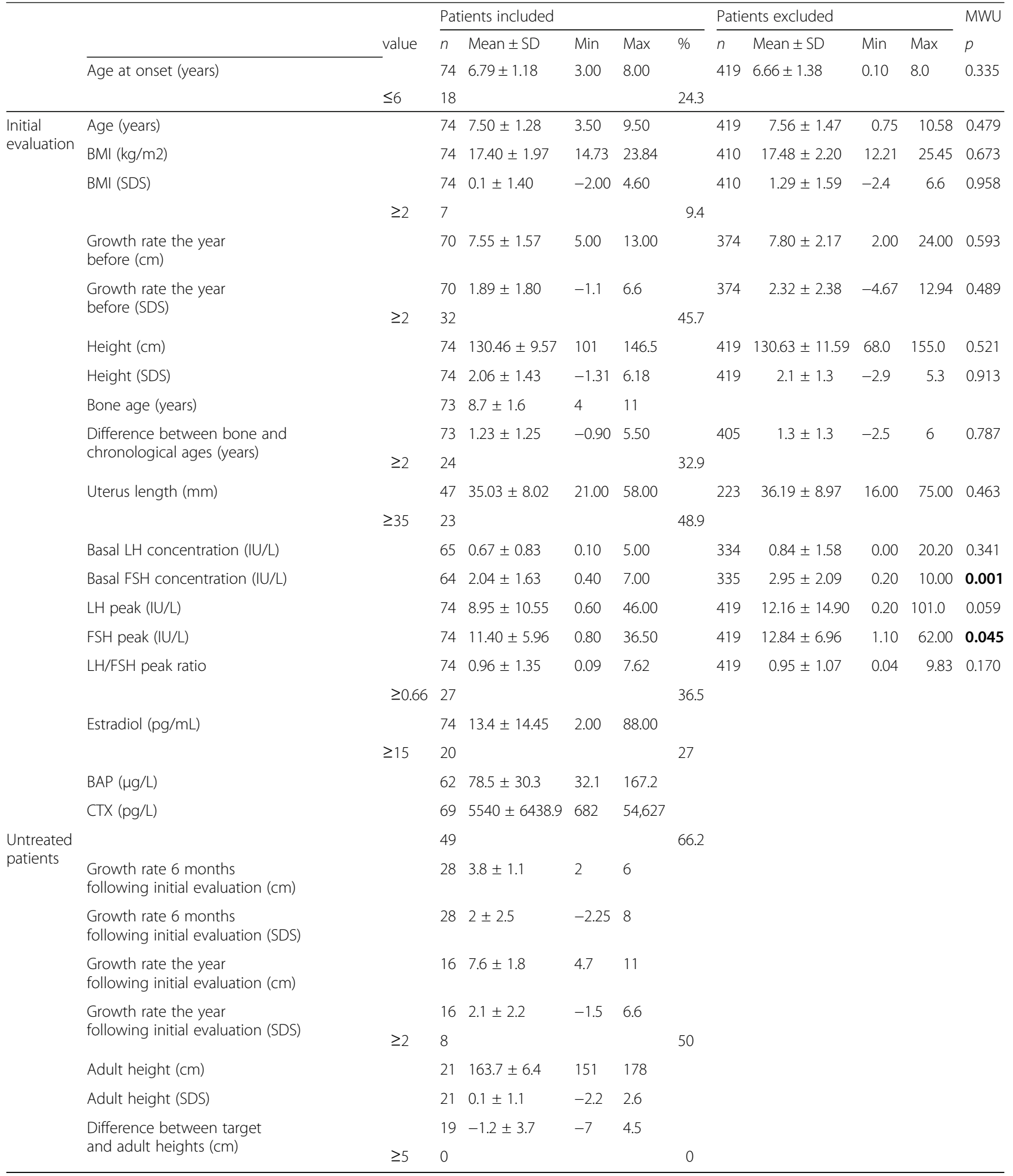

Values are presented as mean \pm standard deviation, minimum and maximum. $P$-values were calculated with Mann Whitney $U$ test

$B M I$ body mass index, SDS standard deviation score, $L H$ luteinizing hormone, FSH follicle stimulating hormone, BAP bone alkaline phosphatase, CTX C-terminal telopeptide of type I collagen crosslinks, $n$ number of patients analyzed, MWU Mann Whitney $U$ test

Bold data correspond to significant $p$ values 
an LH/FSH peak ratio $>0.66(n=17)$, and/or a serum estradiol concentration $>15 \mathrm{pg} / \mathrm{mL} \quad(n=8)$. Treatment (D-Trp-GnRH, 3.75 mg, i.m., every 24-26 days; half doses in patients weighing $<20 \mathrm{~kg}$ ) was continued for at least 2 years. Among the untreated CPP patients, growth rate at 6 months and one year after initial evaluation were available for $57.1 \%(n=28 / 49)$ and $32.6 \%(n=16 / 49)$, respectively. AH was available for $42.8 \%(n=21 / 49)$ of these patients.

The following data were collected at the initial evaluation: age at onset of puberty (corresponding to the age at breast development) and at initial evaluation; pubertal stage; height; body mass index (weight in $\mathrm{kg} /$ height in $\mathrm{m}^{2}$ ); growth rate the year before evaluation; BA; and evaluation of the hypothalamic-pituitary-ovarian axis by measuring basal and GnRH-stimulated LH and FSH peaks and the serum concentration of estradiol. A pelvic ultrasound was performed in 47 patients. The ensuing examinations included height and growth rate at 6 months and 1 year in the untreated girls.

Height (measured in all by R.Brauner with a Harpenden stadiometer), growth rate and body mass index are expressed as SDS for chronological age [20,21]. The pubertal stage was rated according to Marshall and Tanner [22]. BA was assessed by R. Brauner for all patients according to the Greulich and Pyle method [23]. Target height was calculated based on parental heights reported by the parents [24].

$\mathrm{LH}$ and FSH concentrations were measured using a two-site monoclonal immunoradiometric assay (LH-Coatria and FSH-Coatria; bioMerieux, SA, Marcy-l'Etoile, France). Estradiol was extracted with ether and measured by radioimmunoassay (Estradiol-2; Sorin Biomedica, Antony, France). BAP and CTX concentrations were assessed by means of chemiluminescent immunoassays using the Cobas automated platform (Roche Diagnostic, Meylan, France).

For the GnRH stimulation test, we used Relefact $\left(100 \mu \mathrm{g} / \mathrm{m}^{2}\right)$ with serum samples collected at $0,30,60$ and $90 \mathrm{~min}$ after the injection. Serum LH, FSH and estradiol concentrations were measured using various radioimmunoassays during the study period. Each new assay for a given hormone was cross-correlated with the previous method to ensure comparable results for a given parameter throughout the study period. The following values were considered to be pubertal: uterus length $>35 \mathrm{~mm}, \mathrm{LH} / \mathrm{FSH}$ peak ratio after GnRH test > 0.66 , and serum estradiol concentration $>15 \mathrm{pg} / \mathrm{mL}$ (55 pmol/L).

\section{Statistical analysis}

The numeric data are expressed as the mean \pm standard deviation. Differences in auxological and clinical data between groups were analyzed using the Mann Whitney $U$ test. Correlations were assessed with Spearman's using GraphPad Prism (GraphPad Software Inc., San Diego, CA, USA). The magnitudes of correlation are expressed as trivial $(r<0.1)$, small $(0.1<r<0.3)$, moderate $(0.3$ $<r<0.5)$, large $(0.5<r<0.7)$, very large $(0.7<r<0.9)$, and nearly perfect $(r>0.9)$ [25]. A $p$ value $<0.05$ was considered significant.

\section{Results}

Characteristics at initial evaluation (Table 1)

According to Tanner breast stage development, 62\% of patients were stage $2(n=46 / 74), 36.5 \%$ were stage $3(n=27 / 74)$ and $1.5 \%$ were stage $4(n=1 / 74)$. Breast development was associated with 1 additional pubertal sign $(n=20 / 74 ; 27 \%), 2$ additional pubertal signs $(n=21$ / 74 ; 28.4\%), 3 additional pubertal signs ( $n=16 / 74 ; 21.6 \%)$, 4 additional pubertal signs $(n=9 / 74 ; 12.2 \%)$ or 5 additional pubertal signs $(n=4 / 74 ; 5.4 \%)$ (See Participants). One patient (1.5\%) exhibited all the pubertal signs evaluated, whereas 3 (4\%) had isolated breast development.

\section{Correlations (Table 2)}

The serum BAP concentration showed moderate significant positive correlations with height in SDS at initial evaluation $(n=62 ; r=0.31 ; p=0.015)$ and with the difference between bone and chronological ages $(n=61 ; r=0.39 ; p=0.002)$ and a small positive correlation with the serum basal FSH concentration $(n=57$; $r=0.27 ; p=0.042$ ) (Fig. 1).

The serum CTX concentration showed a small significant positive correlation with growth rate in $\mathrm{cm}(n=65$; $r=0.26 ; p=0.035)$ and a moderate correlation with growth rate in SDS $(\mathrm{n}=65 ; r=0.34 ; p=0.006)$ the year before the initial evaluation (Fig. 2).

There was no correlation between BAP and CTX concentrations. Furthermore, there were no correlations of serum BAP or CTX concentrations with age at onset of puberty, age at initial evaluation, body mass index, BA, basal LH concentration, FSH or LH peak, LH/FSH ratio, or estradiol concentration.

Among the untreated patients, there was no correlation of BAP or CTX concentrations with growth rate at 6 months or 1 year (in $\mathrm{cm}$ and SDS) after diagnosis.

The mean AH in untreated patients was $163.7 \pm$ $6.4 \mathrm{~cm}$. Height at the initial evaluation and $\mathrm{AH}$ were largely positively correlated $(n=21 ; r=0.58 ; p=0.005)$. The BAP concentration was largely positively correlated with $\mathrm{AH}$ in $\mathrm{cm}$ and in SDS $(n=19 ; \mathrm{r}=0.58 ; p=0.009$ for both) in untreated patients (Fig. 1).

\section{Discussion}

The objective of the present study was to evaluate the relationship between the serum concentrations of BAP and CTX and the growth rate and $\mathrm{AH}$ in girls 
Table 2 Correlations between BAP and CTX and characteristics of girls with CPP

\begin{tabular}{|c|c|c|c|c|c|c|c|c|c|}
\hline & & BAP & & & & CTX & & & \\
\hline & & $n$ & $r$ & IC 95\% & $p$ & $n$ & $r$ & IC 95\% & $p$ \\
\hline All patients & Age at onset of puberty (years) & 62 & -0.15 & $-0.40 ; 0.11$ & 0.232 & 69 & 0.05 & $-0.2 ; 0.29$ & 0.711 \\
\hline & Age at initial evaluation (years) & 62 & -0.17 & $-0.41 ; 0.09$ & 0.180 & 69 & 0.01 & $-0.23 ; 0.25$ & 0.941 \\
\hline & BMI (SDS) & 62 & 0.04 & $-0.22 ; 0.29$ & 0.752 & 69 & -0.04 & $-0.28 ; 0.21$ & 0.761 \\
\hline & $\begin{array}{l}\text { Growth rate the year before } \\
\text { initial evaluation }(\mathrm{cm})\end{array}$ & 60 & 0.21 & $-0.05 ; 0.45$ & 0.100 & 65 & 0.26 & $0.01 ; 0.48$ & 0.035 \\
\hline & $\begin{array}{l}\text { Growth rate the year before initial } \\
\text { evaluation (SDS) }\end{array}$ & 60 & 0.10 & $-0.17 ; 0.35$ & 0.446 & 65 & 0.34 & $0.09 ; 0.54$ & 0.006 \\
\hline & Height at initial evaluation (cm) & 62 & 0,10 & $-0.16 ; 0.35$ & 0.424 & 69 & 0.09 & $-0.16 ; .32$ & 0.480 \\
\hline & Height at initial evaluation (SDS) & 62 & 0.31 & $0.06 ; 0.52$ & 0.015 & 69 & 0.21 & $-0.03 ; 0.43$ & 0.078 \\
\hline & Bone age (years) & 61 & 0.19 & $-0.08 ; 0.42$ & 0.151 & 68 & 0.07 & $-0.18 ; 0.31$ & 0.566 \\
\hline & $\begin{array}{l}\text { Difference between bone and } \\
\text { chronological ages (years) }\end{array}$ & 61 & 0.39 & $0.15 ; 0.59$ & 0.002 & 68 & 0.07 & $-0.18 ; 0.31$ & 0.566 \\
\hline & $\mathrm{BAP}(\mu \mathrm{g} / \mathrm{L})$ & & & & & 57 & 0.19 & $-0.08 ; 0.44$ & 0.153 \\
\hline & Basal LH concentration (IU/L) & 58 & 0.07 & $-0.20 ; 0.33$ & 0.606 & 60 & 0.15 & $-0.11 ; 0.4$ & 0.243 \\
\hline & Basal FSH concentration (IU/L) & 57 & 0.27 & $0.00 ; 0.50$ & 0.042 & 59 & -0.02 & $-0.28 ; 0.24$ & 0.860 \\
\hline & LH peak (IU/L) & 62 & 0.24 & $-0.02 ; 0.47$ & 0.063 & 69 & 0.12 & $-0.13 ; 0.35$ & 0.346 \\
\hline & FSH peak (IU/L) & 62 & 0.10 & $-0.16 ; 0.35$ & 0.448 & 69 & 0.01 & $-0.23 ; 0.25$ & 0.935 \\
\hline & LH/FSH peak ratio & 62 & 0.14 & $-0.12 ; 0.39$ & 0.263 & 69 & 0.10 & $-0.15 ; 0.33$ & 0.415 \\
\hline & Estradiol (pg/mL) & 62 & 0.16 & $-0.10 ; 0.40$ & 0.206 & 69 & -0.06 & $-0.3 ; 0.19$ & 0.618 \\
\hline Untreated patients & $\begin{array}{l}\text { Growth rate } 6 \text { months following } \\
\text { initial evaluation (SDS) }\end{array}$ & 25 & 0.17 & $-0.25 ; 0.54$ & 0.406 & 24 & -0.02 & $-0.43 ; 0.40$ & 0.928 \\
\hline & $\begin{array}{l}\text { Growth rate the year following } \\
\text { initial evaluation (SDS) }\end{array}$ & 13 & 0.31 & $-0.31 ; 0.74$ & 0.306 & 13 & -0.18 & $-0.67 ; 0.43$ & 0.566 \\
\hline & Adult height $(\mathrm{cm})$ & 19 & 0.58 & $0.16 ; 0.82$ & 0.009 & 17 & 0.04 & $-0.46 ; 0.52$ & 0.874 \\
\hline & Adult height (SDS) & 19 & 0.58 & $0.15 ; 0.82$ & 0.009 & 17 & 0.04 & $-0.46 ; 0.53$ & 0.869 \\
\hline & $\begin{array}{l}\text { Difference between target and } \\
\text { adult heights }(\mathrm{cm})\end{array}$ & 17 & -0.19 & $-0.63 ; 0.33$ & 0.453 & 15 & -0.23 & $-0.67 ; 0.33$ & 0.404 \\
\hline
\end{tabular}

Serum BAP concentrations were available for 62 patients including 42 untreated patients Serum CTX concentrations were available for 69 patients including 44 untreated patients $B A P$ bone alkaline phosphatase, $C T X$ C-terminal telopeptide of type I collagen crosslinks, BMI body mass index, SDS standard deviation score, $L H$ luteinizing hormone, FSH follicle stimulating hormone

Bold data correspond to significant $p$ values

with CPP. BAP displayed significant positive correlations with the following parameters at initial evaluation: height in SDS, difference between bone and chronological ages, and serum basal FSH concentration. Moreover, serum BAP was positively correlated with $\mathrm{AH}$ in untreated patients who had spontaneous growth. The CTX concentration displayed a significant positive correlation with growth rate the year before the initial evaluation.

\section{Serum BAP concentration in girls with CPP}

Based on the results of this study, serum BAP can serve as a marker of growth and bone maturation. A positive correlation between BAP and height was described in some previous studies $[6,26]$ but was not confirmed by other studies $[4,7,27]$. However, these former studies differ from the present study by several criteria, including different technical assessments of BAP and CTX concentrations (use a wheat germ agglutinin assay) [4], different studied populations (obese patients and post-pubertal patients) [4, 7], and different comparisons of bone markers to height (in cm but not in SDS) [4].

$\mathrm{CPP}$ can reduce growth potential because premature secretion of estradiol accelerates BA progression, followed by a reduction in growing period and subsequently in growth potential. In the present study, $32.9 \%$ of patients encountered a significant BA advance (a difference of greater than 2 years between bone and chronological ages). The positive correlation between the BAP level and BA advance suggests that BAP concentrations give an approach of epiphyseal maturation and may be useful in predicting the $\mathrm{AH}$. 


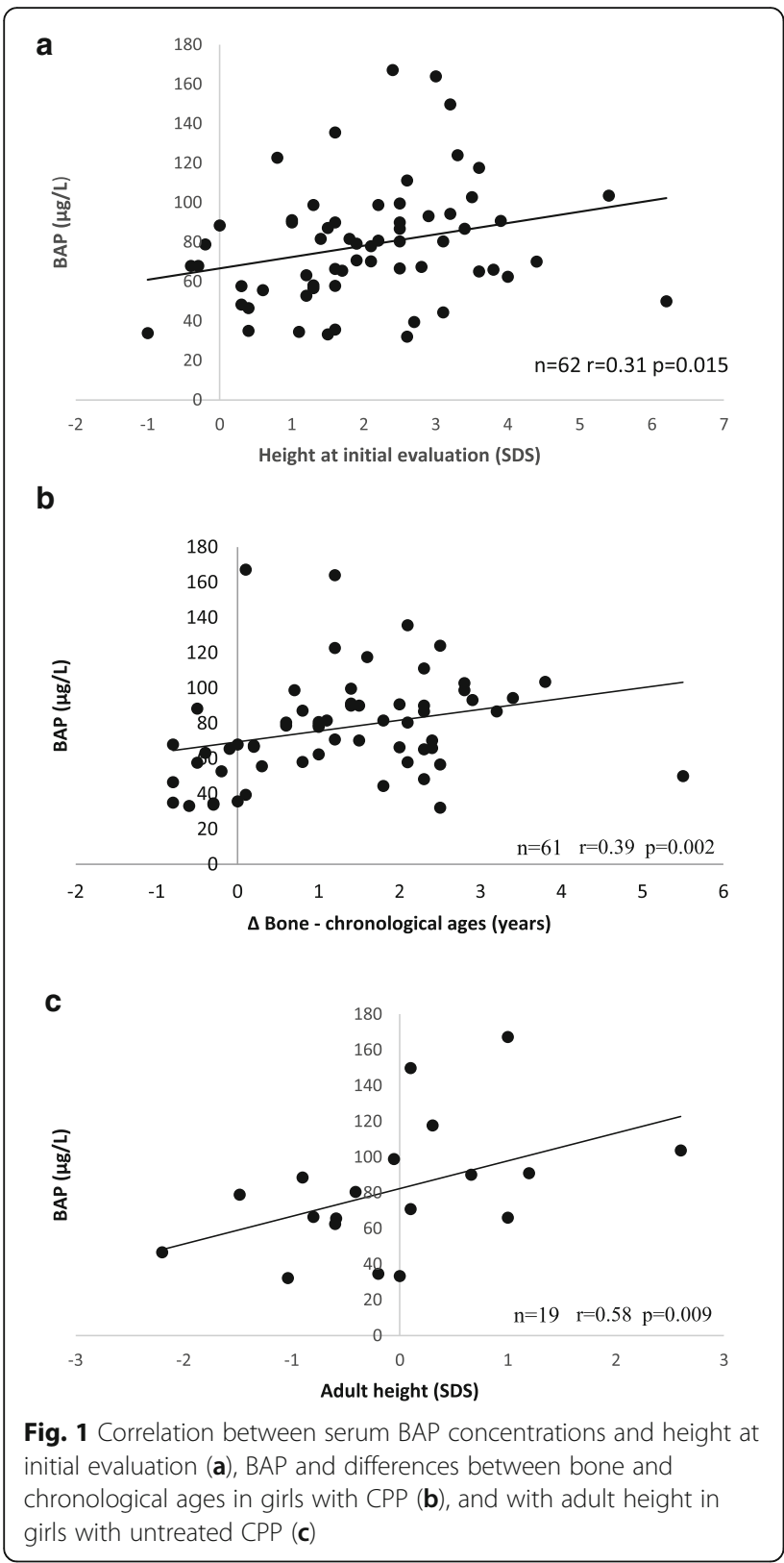

We found the BAP concentration to be positively correlated with $\mathrm{AH}$ in untreated patients with $\mathrm{CPP}$. No study to date has evaluated such a correlation. The fact that BAP was correlated with height at initial evaluation, $\mathrm{BA}$ advance and $\mathrm{AH}$ is consistent with the tables proposed by Bayley and Pinneau for predicting $\mathrm{AH}$, which were based on height at evaluation associated with BA at the time of assessment [28]. Specific tables were established in patients with advanced $\mathrm{BA}$, and although this method is currently controversial because it is considered to overestimate $\mathrm{AH}$, it has been used for decades.
Moreover, the fact that BAP was correlated with both height at initial evaluation and $\mathrm{AH}$ is consistent with previous studies showing that height at treatment initiation in girls with CPP is the most important positive factor influencing $\mathrm{AH}[29,30]$. This finding is reinforced by the fact that we found a large correlation between height at initial evaluation and $\mathrm{AH}$. Recently designed mathematical models predict $\mathrm{AH}$ in patients with $\mathrm{CPP}$ [19] by using mother and father heights and the following data at initial evaluation: chronological age, height, and LH/FSH peak ratio. The correlation between BAP and $\mathrm{AH}$ suggests that it can be used as an additional tool to predict $\mathrm{AH}$, potentially assisting with the decision of whether to introduce treatment with a GnRH analog. This has to be evaluated.

BAP was positively correlated with basal FSH concentrations but not with the LH/FSH peak ratio. A link between serum BAP and FSH concentrations has not yet been reported.

\section{Serum CTX concentration in girls with CPP}

The serum CTX concentration was positively correlated with growth rate the year before the initial evaluation. This result is consistent with several studies demonstrating the link between growth rate and bone markers more specifically during puberty, in children with a normal age of puberty onset $[2,4,6]$. Growth rates and serum bone markers concentrations (BAP, alkaline phosphatase, osteocalcin, procollagen type I propeptide, type I carboxyterminal telopeptide) increase significantly in puberty compared to the prepubertal period, reaching a peak at Tanner breast stage 3, after which they decrease to reach the adult concentration just as the growth rate slows. No study thus far has evaluated the correlation between bone markers and growth rate in children with CPP.

\section{Strengths and limitations}

A strength of our study is that we performed a homogeneous and comparable evaluation of all patients. Except for the classification of the pubertal stage, the evaluation criteria were all objective (quantitative). However, the evaluation of all patients by the same hospital practitioner allows for homogenization of this partially subjective result. In addition, as bone remodeling markers are correlated with the acquisition of bone mass in girls during puberty [4], the evaluation of these markers may allow for optimal treatment of patients whose bone mass is insufficient.

This study has limitations. It is a retrospective study, but the large number of patients and the use of a single investigator limited this bias. Although $\mathrm{AH}$ after spontaneous growth was available for only 21 (42.8\% of the untreated) of the patients, the correlation is large. The 


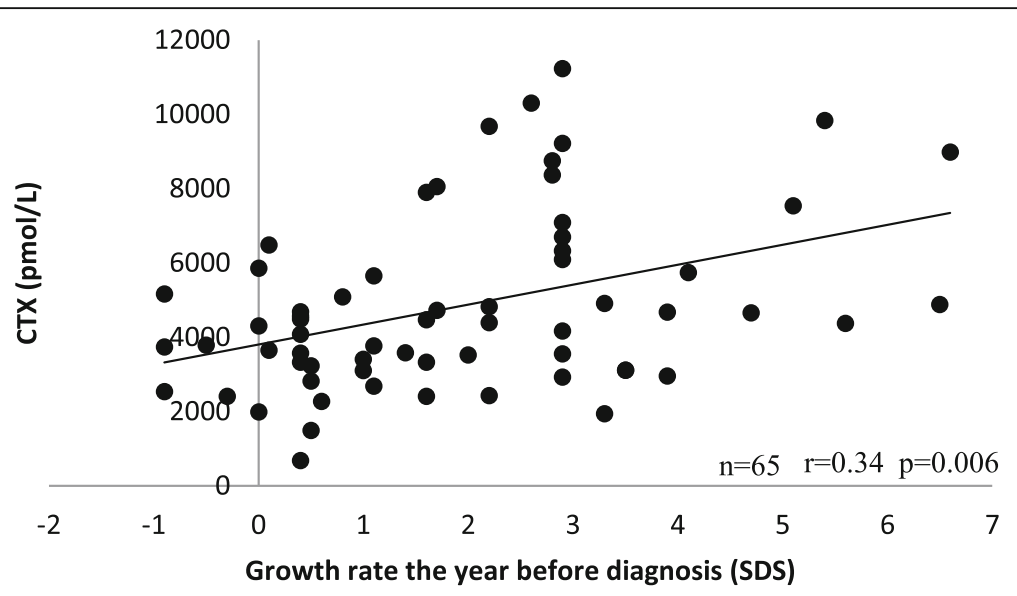

Fig. 2 Correlation between CTX and growth rate the year before initial evaluation in girls with CPP. An extreme value of CTX (54,627 pmol/L) was removed for better visibility

exclusion of girls due to the absence of an available blood sample may have introduced bias. We postulate that the similarity among the data from these girls to the patients who were included, with regard to the variables analyzed (except for FSH basal and peak concentrations), limits this bias. This study did not have a control population of the same pubertal stage. The $\mathrm{AH}$ of the parents weren't measured but reported which may have introduce bias [31].

\section{Conclusions}

In conclusion, this study showed a significant correlation between serum BAP concentrations and $\mathrm{AH}$ in untreated girls with idiopathic CPP. The results also revealed several correlations with precocious pubertal features. Therefore, these bone markers could be possibly used to optimize models of AH prediction in girls with CPP.

\section{Abbreviations}

AH: adult height; BA: bone age; BAP: bone alkaline phosphatase; CPP: central precocious puberty; CTX: C-terminal telopeptide of type I collagen crosslinks; FSH: follicle stimulating hormone; GnRH: gonadotropin-releasing hormone; LH: luteinizing hormone; SDS: standard deviation score

\section{Funding}

The study was self-funded.

\section{Availability of data and materials}

The data that support the findings of this study are available from the corresponding author upon reasonable request.

\section{Authors' contributions}

AV drafted the manuscript, collected and analyzed the data; JCS participated in the design of the study and drafted the manuscript; RB conceived the study and participated in its design and coordination and drafted the manuscript. All the authors read and approved the final manuscript.

\section{Ethics approval and consent to participate}

All clinical investigations were conducted according to the principles outlined in the Declaration of Helsinki. Written informed consent for the evaluation was obtained from the children's parents and included in their hospital medical record. With the exception of routine patient care, no other activities were performed for the study. The authors had no direct interaction with the patients enrolled in the study, except for their medical follow-up, which was performed by R. Brauner. Patients derived from a previous study [12] which was approved by the Ethical Review Committee (Comité de Protection des Personnes, lle de France III) (Ref. CPP: AC 038), which states that "This study appears to be in accordance with scientific principles generally accepted and to ethical standards of research; this study was lead in the respect of the French law and regulation".

Consent for publication

Not applicable.

\section{Competing interests}

The authors declare that they have no financial and non-financial competing interests.

\section{Publisher's Note}

Springer Nature remains neutral with regard to jurisdictional claims in published maps and institutional affiliations.

\section{Author details}

${ }^{1}$ Fondation Ophtalmologique Adolphe de Rothschild and Université Paris Descartes, 75940 Paris, France. ${ }^{2}$ Hôpital Necker-Enfants Malades, Service d'Explorations Fonctionnelles, Assistance Publique-Hôpitaux de Paris, 75743 Paris, France.

Received: 27 March 2018 Accepted: 26 June 2018

Published online: 09 July 2018

\section{References}

1. Delmas PD, Eastell R, Garnero P, Seibel MJ, Stepan J, Committee of Scientific Advisors of the International Osteoporosis Foundation]. The use of biochemical markers of bone turnover in osteoporosis. Committee of Scientific Advisors of the International Osteoporosis Foundation. Osteoporos Int J Establ Result Coop Eur Found Osteoporos Natl Osteoporos Found USA. 2000;11(Suppl 6):S2-17.

2. Szulc P, Seeman E, Delmas PD. Biochemical measurements of bone turnover in children and adolescents. Osteoporos Int J Establ Result Coop Eur Found Osteoporos Natl Osteoporos Found USA. 2000;11 (4):281-94.

3. Blumsohn A, Hannon RA, Wrate R, Barton J, al-Dehaimi AW, Colwell A, et al. Biochemical markers of bone turnover in girls during puberty. Clin Endocrinol. 1994;40(5):663-70.

4. van Coeverden SCCM, Netelenbos JC, de Ridder CM, Roos JC, Popp-Snijders C. Delemarre-van de Waal HA. Bone metabolism markers and bone mass in healthy pubertal boys and girls. Clin Endocrinol. 2002;57(1):107-16. 
5. Chailurkit L, Suthutvoravut U, Mahachoklertwattana P, Charoenkiatkul S, Rajatanavin R. Biochemical markers of bone formation in Thai children and adolescents. Endocr Res. 2005;31(3):159-69.

6. Rauchenzauner M, Schmid A, Heinz-Erian P, Kapelari K, Falkensammer G, Griesmacher A, et al. Sex- and age-specific reference curves for serum markers of bone turnover in healthy children from 2 months to 18 years. J Clin Endocrinol Metab. 2007;92(2):443-9.

7. Alberti C, Chevenne D, Mercat I, Josserand E, Armoogum-Boizeau P, Tichet J, et al. Serum concentrations of insulin-like growth factor (IGF)-1 and IGF binding Protein-3 (IGFBP-3), IGF-1/IGFBP-3 ratio, and markers of bone turnover: reference values for French children and adolescents and z-score comparability with other references. Clin Chem. 2011;57(10):1424-35.

8. Carel J-C, Eugster EA, Rogol A, Ghizzoni L, Palmert MR. ESPE-LWPES GnRH analogs consensus conference group, et al. consensus statement on the use of gonadotropin-releasing hormone analogs in children. Pediatrics. 2009;123(4):e752-62.

9. Chemaitilly W, Trivin C, Adan L, Gall V, Sainte-Rose C, Brauner R. Central precocious puberty: clinical and laboratory features. Clin Endocrinol. 2001; 54(3):289-94.

10. de Vries L, Kauschansky A, Shohat M, Phillip M. Familial central precocious puberty suggests autosomal dominant inheritance. J Clin Endocrinol Metab. 2004;89(4):1794-800.

11. Durand A, Bashamboo A, McElreavey K, Brauner R. Familial early puberty: presentation and inheritance pattern in 139 families. BMC Endocr Disord [Internet]. 2016 [cited 2018 Apr 23];16(1). Available from: http:// bmcendocrdisord.biomedcentral.com/articles/10.1186/s12902-016-0130-x

12. Giabicani E, Allali S, Durand A, Sommet J, Couto-Silva A-C, Brauner R. Presentation of 493 consecutive girls with idiopathic central precocious puberty: a single-center study. PLoS One. 2013;8(7):e70931.

13. Brauner R, Adan L, Malandry F, Zantleifer D. Adult height in girls with idiopathic true precocious puberty. J Clin Endocrinol Metab. 1994;79(2):415-20.

14. Palmert MR, Malin HV, Boepple PA. Unsustained or slowly progressive puberty in young girls: initial presentation and long-term follow-up of 20 untreated patients. J Clin Endocrinol Metab. 1999;84(2):415-23.

15. Fontoura M, Brauner R, Prevot C, Rappaport R. Precocious puberty in girls: early diagnosis of a slowly progressing variant. Arch Dis Child. 1989;64(8): 1170-6

16. Willemsen RH, Elleri D, Williams RM, Ong KK, Dunger DB. Pros and cons of GnRHa treatment for early puberty in girls. Nat Rev Endocrinol. 2014;10(6): 352-63.

17. Cassio A, Cacciari E, Balsamo A, Bal M, Tassinari D. Randomised trial of LHRH analogue treatment on final height in girls with onset of puberty aged 7.58.5 years. Arch Dis Child. 1999;81(4):329-32.

18. Klein KO, Barnes KM, Jones JV, Feuillan PP, Cutler GB. Increased final height in precocious puberty after long-term treatment with LHRH agonists: the National Institutes of Health experience. J Clin Endocrinol Metab. 2001; 86(10):4711-6

19. Giabicani E, Lemaire $P$, Brauner R. Models for predicting the adult height and age at first menstruation of girls with idiopathic central precocious puberty. Wolfe A, editor PLOS ONE. 2015;10(4):e0120588.

20. Rolland-Cachera MF, Cole TJ, Sempé M, Tichet J, Rossignol C, Charraud A. Body mass index variations: centiles from birth to 87 years. Eur J Clin Nutr. 1991;45(1):13-21.

21. Sempé A, Pedron G, Roy-Pernot M-P. Auxologie, méthode et séquences, Paris. Laboratoire Théraplix; 1979

22. Marshall WA, Tanner JM. Variations in pattern of pubertal changes in girls. Arch Dis Child. 1969:44(235):291-303.

23. Greulich WW, Pyle SI. Radiographic atlas of skeletal development of the hand and wrist. 2nd edition. I volume-atlante di 256 pagine. Stanford University press, Stanford, California, 1959. Acta Genet Med Gemellol. 1959; 8(04):513.

24. Tanner JM, Goldstein H, Whitehouse RH. Standards for Children's height at age 2 to 9 years allowing for height of parents. Arch Dis Child. 1970:45(244):819.

25. Hopkins WG, Marshall SW, Batterham AM, Hanin J. Progressive statistics for studies in sports medicine and exercise science. Med Sci Sports Exerc. 2009; 41(1):3-13.

26. Mora S, Cafarelli L, Erba P, Puzzovio M, Zamproni I, Giacomet V, et al. Differential effect of age, gender and puberty on bone formation rate assessed by measurement of bone-specific alkaline phosphatase in healthy Italian children and adolescents. J Bone Miner Metab. 2009:27(6):721-6.
27. Gajewska J, Klemarczyk W, Ambroszkiewicz J, Szamotulska K, Chełchowska M, Weker H. Associations between IGF-I, IGF-binding proteins and bone turnover markers in prepubertal obese children. J Pediatr Endocrinol Metab [Internet]. 2015 [cited 2018 Apr 23];28(5-6). Available from: https://www. degruyter.com/view/j/jpem.2015.28.issue-5-6/jpem-2014-0326/jpem-20140326.xml

28. Bayley N, Pinneau SR. Tables for predicting adult height from skeletal age: revised for use with the Greulich-Pyle hand standards. J Pediatr. 1952:40(4):423-41.

29. Pasquino AM, Pucarelli I, Accardo F, Demiraj $V$, Segni M, Di Nardo R. Long-term observation of 87 girls with idiopathic central precocious puberty treated with gonadotropin-releasing hormone analogs: impact on adult height, body mass index, bone mineral content, and reproductive function. J Clin Endocrinol Metab. 2008;93(1):190-5.

30. Oostdijk W, Rikken B, Schreuder S, Otten B, Odink R, Rouwé C, et al. Final height in central precocious puberty after long term treatment with a slow release GnRH agonist. Arch Dis Child. 1996;75(4):292-7.

31. Cizmecioglu F, Doherty A, Paterson WF, Young D, Donaldson MDC. Measured versus reported parental height. Arch Dis Child. 2005:90(9):941-2.

\section{Ready to submit your research? Choose BMC and benefit from:}

- fast, convenient online submission

- thorough peer review by experienced researchers in your field

- rapid publication on acceptance

- support for research data, including large and complex data types

- gold Open Access which fosters wider collaboration and increased citations

- maximum visibility for your research: over $100 \mathrm{M}$ website views per year

At BMC, research is always in progress.

Learn more biomedcentral.com/submissions 